\title{
KAPABILITAS PEMASARAN DAN OPERASI SERTA PENGARUHNYA PADA SUPPLY CHAIN MANAGEMENTDAN KINERJA PERUSAHAAN
}

\author{
Hadi Purnomo \\ Fakultas Ekonomi, UKRIM Yogyakarta \\ hadipurnomoklaten@gmail.com \\ Edi Santosa \\ Fakultas Ekonomi, UKRIM Yogyakarta \\ masstedi@gmail.com
}

\begin{abstract}
Competition is a fact that needs to be faced by companies, and competitive advantage is thecore of the company's success. To face the competition, the accuracy of the strategy undertaken by a company is one of the key success factors of the company. The strategy is to focus on the important factors that affect the performance of the company. In this case, two functions that are key to the creation of value-added are marketing and operations functions. Operations and marketing capabilities are important factors to obtain superior performance. Integration of marketing and operations (operation capabilities, marketing capabilities) is believed to be a synergy to achieve the company's competitive advantage.On the other hand, Supply Chain Management (SCM) is a key strategic factor to improve the company effectiveness. While an effective supply chain process is based on cross-functional collaboration of the company including operations and marketing capabilities. Thus, the main concern of this study is to focus on the influence of operationand marketing capabilities in supply chain integration and the firm performance, as well as the effect of supply chain integration on the firm performance. The results of this study based on regression analysis show that the regression coefficient of each independent variable on the dependent variable is positive. This means that the marketing and operation capabilities have positive effects on the firm performance, as well as having a positive impact on the supply chain integration. On the other side, the supply chain integration also has a positive effect on the firm performance.
\end{abstract}

Keywords: integration of marketing and operations, supply chain management (SCM), firm performance 


\section{PENDAHULUAN}

Globalisasi dan teknologi memiliki pengaruh yang kuat atas perubahanperubahan yang terjadi. Perubahan lingkungan bisnis seperti persaingan yang semakin sengit, tuntutan konsumen akan produk dengan mutu yang tinggi, harga murah serta pengiriman tepat waktu, daur hidup produk yang semakin pendek dan kemajuan dalam bidang teknologi menuntut pengelola bisnis untuk menciptakan model-model baru dalam pengelolaan aliran produk (Watanabe 2001). Gunasekaran et al. (1999) dalam Purnomo (2007) menekankan pada kemampuan untuk merespon perubahan dengan pengelolaan aliran produk.

Kondisi perekonomian dan bisnis telah berkembang semakin cepat dan kompleks. Perubahan dalam lingkungan bisnis mendorong persaingan bisnis yang semakin kompetitif. Persaingan dalam dunia bisnis di Indonesia salah satunya dalam sektor properti, khususnya perumahan. Sektor properti telah berkembang seiring kebutuhan masyarakat yang meningkat akan tempat tinggal. Demikian juga pertumbuhan kebutuhan akan tempat tinggal yang layak di Yogyakarta menciptakan potensi pasar perumahan yang sangat besar, hal ini ditunjukkan dengan meningkatnya pembangunan kawasan perumahan baru. Kondisi tersebut menciptakan persaingan ketat antarpengembang (developer) untuk menyediakan perumahan bagi masyarakat.

Persaingan merupakan fakta yang perlu dihadapi oleh perusahaan dan keunggulan bersaing adalah inti keberhasilan maupun kegagalan perusahaan. Untuk menghadapi persaingan tersebut, ketepatan strategi yang dilakukan oleh perusahaan menjadi salah satu faktor kunci keberhasilan perusahaan.Porter (1993) mengatakan bahwa keunggulan bersaingadalah jantung dari kinerja perusahaan untuk bersaing dan berkembang dari nilai yang perusahaan mampu ciptakan bagi pelanggan dan dapat mempertahankan diri dari tekanan-tekanan kompetitif pasar. Ma'arif (2003) mengemukakan bahwa persaingan atau kompetisi merupakan kunci sukses perusahaan. Perubahan lingkungan yang cepat mendorong perusahaan untuk mencari cara-cara bagaimana mengendalikan risiko dan ketidakpastian. Perubahan lingkungan bisnis memaksa perusahaan untuk menyesuaikan strateginya melalui strukturisasi organisasi, penciptaan tim lintas fungsi (cross function team) dan inovasi sebagai strategi efektif (Calantone et al., 2003). Organisasi berusaha mendapatkan cara-cara untuk mempertahankan dan meningkatkan kinerja perusahaan dalam lingkungan bisnis yang tidak menentu.

Penelitian-penelitian tentang organisasi memberikan sejumlah saran untuk memaksimalkan kinerja perusahaan dalam situasi tersebut. Persaingan akan menentukan ketepatan aktivitas perusahaan yang dapat mendukung kinerja perusahaan seperti inovasi, budaya kohesif atau pelaksanaan yang baik. Anatan (2006) menyebutkan bahwa sumber keunggulan kompetitif perusahaan dapat ditemukan melalui kemampuan manajemen dalam mengkonsolidasikan kompetensi 
bidang fungsional perusahaan, yaitu kompetensi pemasaran, inovasi serta bidang operasi. Studi terintegrasi dilakukan oleh Deane et al. (1991) yang mengkaitkan antara produksi dan pemasaran. Simpulan studi tersebut ialah bahwa strategi operasi dan pemasaran merupakan prediktor terbaik kesuksessan perusahaan. Menurut Vickery et al. (1994), kompetensi di bidang pemasaran, inovasi dan manufacturing adalah sumber keunggulan kompetitif bagi perusahaan, sehingga kesuksessan perusahaan ditentukan oleh kerja sama, koordinasi dan interegrasi antara bidang pemasaran dan operasi.

Isu khusus yang berkembang berkaitan dengan manajemen pemasaran dan operasional yaitu upaya kerja sama dua bidang tersebut untuk meningkatkan kinerja perusahaan. Ho dan Tang (2004) menyebutkan kerja sama tersebut menyangkut supply dan demand. Pemasaran berusaha menciptakan permintaan konsumen sedangkan manajemen operasi berusaha menyediakan produk untuk memenuhi kebutuhan konsumen. Manajemen pemasaran dan operasional mempunyai hubungan erat pada berbagai perusahaan. Perselisihan kedua bidang ini akan menyebabkan perusahaan bermasalah. Masalah tersebut berkaitan dengan supply dan demand, sehingga mengarah pada ketidakefesiensian dan kesulitan untuk melayani konsumen. Sinkronisasi kedua bidang ini akan menciptakan sinergi untuk meningkatkan daya saing dan profitabilitas perusahaan. Bentuk kerja sama dua bidang ini secara internal dalam perusahaan (intrafirm) dapat dilakukan untuk mewujudkan kerja sama dengan perusahaan lain (interfirm).

Fitzsimmons et al. (1991) menyebutkan hubungan itu sebagai interdepedency, dimana output salah satu fungsi sebagai input bagi fungsi yang lain. Dalam desain organisasi, seringkali hubungan kedua fungsi tersebut disebut dengan inter-functional relationship. Dalam manajemen manufaktur dapat ditunjukkan integrasi tersebut dengan memasangkan operasi dan pemasaran. Praktik interaksi kedua fungsi tersebut dalam transfunctional sangat komplek seperti desain produk, pemasaran industrial dan supply chain. Penelitian Kulp et al. (2003) menunjukkan bahwa pertukaran informasi, sinkronisasi perencanaan serta kolaborasi pengembangan dan desain produk dapat meningkatkan kinerja supply chain. Balasubramanian dan Bhardwarj (1999) menyatakan dimana perusahaan yang mempunyai kerja sama yang baik antara manajemen pemasaran dan operasi akan lebih bersaing dibandingkan perusahaan yang mempunyai konflik pada kedua bidang tersebut. Adapun penelitian Agan (2011) tentang pengaruh pemasaran dan operasi pada supply chain menunjukkan adanya pengaruh positif pada orientasi pasar, seleksi dan kolaborasi partner.

Kompetisi mendorong manajer untuk mencurahkan perhatian yang besar terhadap Supply Chain Management (SCM). SCM merupakan faktor kunci strategis untuk meningkatkan efektifitas perusahaan dan realisasi tujuan perusahaan yang lebih baik. Perusahaan dituntut untuk memilih supply chain dan logistik dalam operasinya. Sebagain besar perusahaan berupaya meningkatkan efisiensi dan 
efektifitas supply chain. Peningkatan kinerja bisnis perusahaan dapat dilakukan dengan kerja sama suplier, kinerja pengiriman, pelayanan konsumen dan pengurangan biaya logistik. Penelitian-penelitian tentang $S C M$ menunjukkan adanya pengaruh positif antara proses $S C M$ dengan kinerja perusahaan. Urumugam dan Mojtahedzadeh (2011) dalam penelitiannya menunjukkan adanya pengaruh positif SCM dengan kinerja perusahaan di industri Iran. Demikian juga Sadeh et al. (2011) menjelaskan hasil penelitiannya yang menunjukkan adanya hubungan positif antara $S C M$, Total Quality Management (TQM) dengan kinerja perusahaan. Penelitian lain yang dilakukan oleh Setiawan dan Santosa (2006) serta Setiawan dan Rahardian (2004) pada industri tekstil di Jawa Tengah dan Jawa Timur memperkuat adanya pengaruh yang positif antara $S C M$ dengan kinerja perusahaan.

Penelitian terdahulu yang dilakukan oleh Krasnikov dan Jayachandran (2008), Agan (2011) dan Alexandru (2012) terbatas pada hubungan kapabilitas pemasaran dan kapabilitas operasi dengan supply chain, maupun dengan kinerja perusahaan saja dan hubungan integrasi supply chain dengan kinerja perusahaan. Penelitian ini dilakukan dengan memadukan hubungan kapabilitas pemasaran dan kapabilitas operasi, integrasi supply chain dan kinerja perusahaan.

\section{RUMUSAN MASALAH}

Berdasarkan latar belakang yang telah diuraikan sebelumnya, maka permasalahan penelitian ini dapat dirumuskan ke dalam dua pertanyaan sebagai berikut.

1. Apakah ada pengaruh positif kapabilitas pemasaran (marketing capability) dankapabilitas operasi (operation capability) pada integrasi supply chain?

2. Apakah ada pengaruh positif kapabilitas pemasarandan kapabilitas operasi pada kinerja perusahaan?

3. Apakah ada pengaruh positif integrasi supply chainpada kinerja perusahaan?

\section{TINJAUAN PUSTAKA}

\section{Kapabilitas Pemasaran dan Operasi}

Perusahaan dalam upayanya untuk mencapai keunggulan bersaing perlu memahami sumber daya internal yang ditranformasikan dalam kapabilitas perusahaan. Kapabilitas merupakan kumpulan skill dan pengetahuan yang didapati dalam proses organisasi, yang merupakan sumber daya penting untuk keunggulan bersaing dan kinerja yang superior. Day (1994) mengibaratkan kapabilitas sebagai lem yang menyatukan sumber daya berbeda secara bersama untuk mencapai keunggulan. Momeni (2011) menyebutkan tentang core competencies perusahaan yang meliputi marketing competencies, technological competencies dan integrative 
competencies. Adapun Agan (2011) menyebutkan adanya tiga kapabilitas berbagai fungsi dalam penelitiannya yaitu kapabilitas information technology, operations dan marketing. Namun demikian, isu fundamental fungsi utama dalam strategi perusahaan meliputi pemasaran dan operasi. Porter (1985) dan Drucker (2007) menyebutkan dua fungsi yang merupakan kunci penciptaan nilai tambah yaitu fungsi pemasaran dan operasi. Kedua fungsi tersebut dikatakan penting karena kegiatannya berhubungan langsung dengan proses menciptakan produk dan menyampaikan pada konsumen. Bidang-bidang yang berhubungan dengan bisnis (SDM dan akuntansi) memang diperlukan untuk penciptaan nilai, namun hanya marketing dan operasi yang berhubungan secara langsung dengan penambahan nilai (Drucker 2007).

Marketing dan operasi merupakan fungsi-fungsi yang penting dalam menciptakan nilai tambah dalam organisasi bisnis. Penambahan nilai dalam operasi dilakukan melalui kegiatan transformasi sumber dayainput (material, modal dan manusia) menjadi output, adapun penambahan nilai dalam marketing dilakukan melalui identifikasi kebutuhan dan permintaan konsumen, penentuan proses dan produk apa dihasilkan untuk melayani kebutuhan konsumen. Fungsi marketing dan operasi berhubungan dengan apa yang diproduksi, bagaimana memproduksi dan mengantarkan produk ke tangan konsumen. Secara fundamental, pemasaran menangani permintaan konsumen, adapun operasi menangani kemampuan memproduksi. Pemasaran mempunyai peran dalam target konsumen, mengidentifikasi permintaan dan menetapkan jumlah permintaan dan produk. Adapun operasi berhubungan dengan kapasitas, fasilitas, teknologi dan pengontrolan kualitas. Operasi tergantung pada marketing untuk peramalan produksi, sedangkan pemasaran tergantung operasi pada penentuan harga, pengembangan produk, pengenalan produk baru dan pelayanan konsumen. Sawhney dan Paper (2002) menunjukkan hubungan marketing dengan operasi memiliki pengaruh utama pada quality, cost dan speed, bagi perusahaan dalam menawarkan produk ke pasar, demikian juga dengan Ho dan Zheng (2004) yang mengemukakan pentingnya faktor marketing dan operasi dalam komitmen waktu memberikan pada konsumen.

Penelitian empiris Krasnikov dan Jayachandran (2008) dilakukan dengan memperbandingkan kapabilitas marketing, operasi dan research development (R\&D). Secara umum hasil-hasil penelitian menunjukkan hubungan positif kapabilitas operasi dan marketing dengan kinerja perusahaan (Day 1994).

a. Kapabilitas pemasaran mempunyai pengaruh positif pada kinerja perusahaan

b. Kapabilitas operasi mempunyai pengaruh positif pada kinerja perusahaan

\section{Pengintegrasian Pemasaran dan Operasi pada Supply Chain Management}

Perusahaan dalam menghadapi era pasar yang kompleks dan tidak bisa diprediksi memerlukan strategi untuk menciptakan keunggulan bersaing. Untuk menghadapi persaingan tersebut maka diperlukan kerja sama yang luas antara pemasaran, operasi dan supply chain(Sarangi dan Srivatsan 2009). Isu khusus yang 
berkembang berkaitan dengan manajemen pemasaran dan operasional yaitu upaya kerja sama dua bidang tersebut untuk meningkatkan kinerja perusahaan. Piercy (2010) menekankan kerja sama antara marketing dengan operasi merupakan hal yang penting bagi kesuksesan bisnis, dimana dalam organisasi kecil maupun menengah atau besar keterkaitan wilayah marketing dan operasi merupakan faktor penting untuk kesuksessan bagi kapabilitas perusahaan untuk menguasai pasar dan memuaskan konsumen. Ho dan Tang (2004) menyebutkan kerja sama tersebut menyangkut supply dan demand. Pemasaran berusaha menciptakan permintaan konsumen sedangkan manajemen operasi berusaha menyediakan produk untuk memenuhi kebutuhan konsumen. Wajar bila manajemen pemasaran dan operasional mempunyai hubungan erat pada berbagai perusahaan. Sinkronisasi kedua bidang ini akan menciptakan sinergi untuk meningkatkan daya saing dan profitabilitas perusahaan. Bentuk kerja sama dua bidang ini secara internal dalam perusahaan (intrafirm) dapat dilakukan untuk mewujudkan kerja sama dengan perusahaan lain (interfirm).

Organisasi dihadapkan pada tugas untuk mengelola kebutuhan konsumen melalui supply chain. Sebagai konsekuensinya seringkali perusahaan menjalankan proses supply chain yang kurang efisien, peningkatan biaya penyimpanan barang dan lead times. Untuk mengatasi situasi tersebut perusahaan memerlukan flexibilitas supply chainyang akan menghasilkan keunggulan untuk produk yang tepat, waktu yang tepat, kualitas menarik dan harga yang kompetitif.

Sarangi and Shreyas (2009) menyimpulkan melalui pendekatan proses, organisasi dapat meningkatakan efisiensi outbond supply chain melalui keterkaitan departemen marketing dan operasi dan strategi untuk memaksimalkan nilai konsumen. Untuk mengatasi kompleksitas diperlukan kerja sama dan sharing informasi antara marketing dan operasi pada outbond supply chain. Ho dan Cristoper (2004) menyarankan koordinasi intrafirm dimana perusahaan yang berbeda perlu bekerja sama untuk memaksimalkan kinerja supply chain melalui kerja samamanajemen marketing dan operasi. Penelitian Kulp et al. (2003) menunjukkan bahwa pertukaran informasi, sinkronisasi perencanaan serta kolaborasi pengembangan dan desain produk dapat meningkatkan kinerja supply chain.

Steckel et al. (2001) menyebutkan penelitian kerja sama tersebut dalam upaya memperpendek product life cycle akan menurunkan cost. Balasubramanian dan Bhardwarj (1999) menyatakan dimana perusahaan yang mempunyai kerja sama yang baik antara manajemen pemasaran dan operasi akan lebih bersaing dibandingkan perusahaan yang mempunyai konflik pada kedua bidang tersebut. Studi terintegrasi dilakukan oleh Deane et al. (1991) yang mengkaitkan antara produksi dan pemasaran. Simpulan studi tersebut ialah bahwa strategi operasi dan pemasaran merupakan prediktor terbaik kesuksesan perusahaan. Menurut Vickery et al. (1994), kompetensi di bidang pemasaran, inovasi dan manufacturing adalah sumber keunggulan kompetitif bagi perusahaan, sehingga kesuksesan perusahaan 
ditentukan oleh kerja sama, koordinasi dan integrasi antara bidang pemasaran dan operasi. Lebih jauh, Kohli dan Jaworski (1990) menjelaskan market orientation sebagai implementasi konsep pemasaran. Market orientation meliputi customer orientation, competitor orientation dan interfunctional coordination. Min dan Mentzer (2000) menjelaskan bahwa market orientation berdampak pada firm relationship.

Lebih lanjutShervani dan Fahey (1999) mengungkapkan market driven supply chainmendukung koordinasi dan integrasi tugas dan kegiatan supply chain integration. Adapun Agan (2011) dalam penelitiannya menjelaskan bahwa operation capabilities yang meliputiselecting partners, collaboration with partners, learning from partners dan business knowledge dan marketing capabilities yang meliputi market orientationmempunyai pengaruh signifikan pada supply chain integration.

a. Kapabilitas pemasaran mempunyai pengaruh positif pada integrasi supply chain.

b. Kapabilitas operasi mempunyai pengaruh positif pada integrasi supply chain.

\section{Integrasi Supply chain}

Persaingan yang ketat menuntut para pengelola bisnis menciptakan modelmodel baru dalam pengelolaan aliran produk. Supply chain Management (SCM) adalah modifikasi praktik tradisional dari manajemen logistik yang bersifat adversial ke arah koordinasi dan kemitraan antar pihak-pihak yang terlibat dalam pengelolaan aliran informasi dalam produk tersebut (Zabidi2001). Menurut Heizer dan Render (2000), SCM adalah mata rantai dimana dari berbagai pemasok kemudian masuk ke pabrikan, grosis, distributor, sampai ke tangan konsumen. SCM merupakan satu hal yang kompleks, kalau permintaan konsumen sendiri sangat fluktuatif, maka perencanaan akan complicated. Sementara perusahaan meningkatkan kemampuan bersaing melalui penyesuaian produk, kualitas tinggi, pengurangan biaya dan kecepatan mencapai pasar. Sebuah supply chain merupakan jaringan dari pelakupelaku yang mentranformasikan bahan mentah sampai dengan mendistribusikan produk (Bowersx et al., 1999). Proses panjang produk sampai pada konsumen menuntut perusahaan bekerja sama dengan perusahaan lain. Komponen-komponen yang membentuk supply chain merupakan sebuah channel. Hubungan jangka panjang dengan channel tersebut memberikan kestabilan pada rantai proses.

SCM merupakan faktor kunci strategis untuk meningkatkan efektifitas perusahaan dan realisasi tujuan perusahaan yang lebih baik. Pada era globalisasi perusahaan dituntut untuk memilih supply chain dan logistik dalam operasinya. Sebagain besar perusahaan berupaya meningkatkan efisiensi dan efektifitas supply chain. Peningkatan kinerja bisnis perusahaan dapat dilakukan dengan kerja sama suplier, kinerja pengiriman, pelayanan konsumen dan pengurangan biaya logistik. Keunggulan kompetitif SCM adalah bagaimana perusahaan mampu mengelola aliran barang atau produk dalam suatu rantai supply. Dengan kata lain model 
SCMmengaplikasikan bagaimana suatu jaringan kegiatan produksi dan distribusi suatu perusahaan dapat bekerja bersama-sama untuk memenuhi tuntutan konsumen. Tujuan utama $S C M$ adalah penyerahan/pengiriman produk secara tepat waktu demi memuaskan konsumen,mengurangi biaya, meningkatkan segala hasil dari seluruh supply chain (bukan hanya satu perusahaan), mengurangi waktu, memusatkan kegiatan perencanaan dan distribusi.

Dalam kontek supply chain, perusahaan cenderung untuk mempertahankan perilaku hubungan jangka panjang, dimana mitra umumnya percaya bahwa mereka dapat saling menguntungkan antara member rantai pasokan (Su et al., 2008), kemitraan yang sama juga berorientasi pada konsep jangka panjang (Smith dan Barclay 1997). Narasimhan et al. (2001) menemukan bahwa integrasi pembelian dan praktek pembelian saling mempengaruhi dan hasil interaksi tersebut telah memberikan dampak positif pada manufacturing performance. Dalam hubungannya dengan proses produksi, praktik supply chain management yang dilaksanakan perusahaan akan memberikan dampak di antaranya terhadap 17 pengelolaan persediaan bahan baku. Apabila pengelolaan persediaan bahan baku dilakukan dengan tepat, maka implikasi yang lebih jauh lagi bagi perusahaan adalah minimalisasi biaya yang dapat mengurangi ketidakefisienan dalam proses produksi. Ketidakefisienan dapat muncul ketika persediaan bahan baku habis, sementara bahan baku yang dipesan perusahaan belum datang. Dalam konteks ini peran supply chain management yang baik menjadi sangat penting artinya, di antaranya melalui jalinan kerja sama yang baik supplier dengan dealer. Fisher (1997) menjelaskan kurangnya kerja sama dengan mitra supply chain menyebabkan kerugian yang cukup besar. Hal ini menunjukkan pentingnya kemitraan dalam supply chain. Kemitraan yang kuat menekankan pada kerja sama yang panjang, mencakup perencanaan yang lebih baik dan upaya pemecahan masalah bersama. Kemitraan pembeli dan pemasok merupakan hal penting yang menjadi perhatian industri dan peneliti.

Penelitian Toni et al. (1994), Maloni dan Benton (1997) menunjukkan tekanan kemitraan untuk operasi supply chain yang lebih baik. Evaluasi efisiensi dan efektifitas kinerja mitra perlu dievaluasi secara menyeluruh. Upaya yang dilakukan yaitu gambaran tujuan yang jelas untuk mempersiapkan langkah-langkah meningkatkan kinerja dan kepercayaan. Faktor-faktor yang berpengaruh pada kepercayaan telah diteliti oleh beberapa peneliti. Kwon dan Taewon mengemukakan faktor karakteristik supplier yang diyakini berpengaruh pada kepercayaan.

Penelitian Stein dan Voehl (1998) menunjukkan supply chain integration meningkatkan efisiensi dan produktifitas. Integrasi para suplier yang efektif pada supply chain merupakan kunci untuk mencapai keunggulan kompetitif. Alexandru (2012) menjelaskan dalam penelitiannya pengaruh supply chain pada kinerja organisasi, dimana berpengaruh positif pada kinerja operasi, keuangan dan konsumen. Urumugam dan Mojtahedzadeh (2011) meneliti tentang hubungan 
SCMdengan kinerja organisasi jasa, menunjukkan adanya pengaruh signifikan SCM pada kinerja.

H1: Integrasi supply chain mempunyai pengaruh positif pada kinerja perusahaan.

\section{MODEL PENELITIAN}

Hubungan antara kapabilitas pemasaran, kapabilitas operasi, integrasi supply chaindan kinerja perusahaan dapat dimodelkan sebagai berikut:

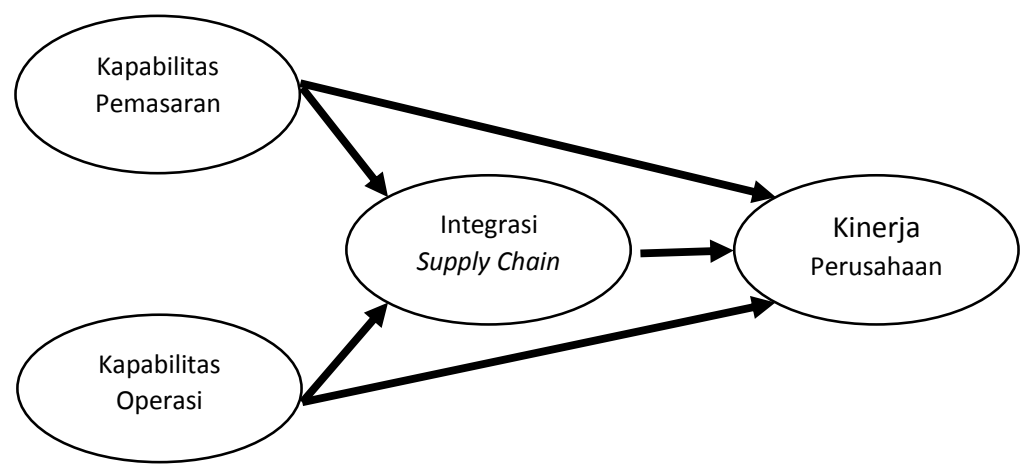

Gambar 1

Model Penelitian

\section{METODA PENELITIAN}

\section{Desain Penelitian}

Penelitian ini dilakukan dengan menggunakan metoda survei dan menggunakan daftar pertanyaan (kuesioner) sebagai instrumen utama dalam pengumpulan data primer. Kuesioner hanya berisi pertanyaan tertutup saja, dimana responden hanya bisa memilih dari pilihan jawaban yang tersedia. Oleh karena keterbatasan waktu dan biaya maka penelitian ini hanya meneliti pada pengembang perumahan di wilayah Yogyakarta.

\section{Sampel dan Pengumpulan Data}

Populasi dalam penelitian ini adalah para retailer. Pemilihan sampel ditetapkan dengan purposive sampling, yaitu memilih sampel dengan kriteria tertentu. Kriteria tersebut adalah manajer pengembang perumahan yang sudah berkegiatan minimal dua tahun. Pengumpulan data diorganisasikan dengan kedua langkah sebagai berikut: langkah pertama, menghubungi berbagai developer via telephone maupun kunjungan langsung. Jumlah sampel ditetapkan 150 orang. Anderson et al. (1998) menyatakan bahwa sampel sebanyak 30 sudah dapat 
memberikan hasil yang valid, walaupun sampel kecil ini tidak direkomendasikan untuk suatu penelitian.

\section{Uji Validitas dan Realibilitas}

Pengujian validitas dilakukan untuk mengetahui sejauh mana ketepatan dan kecermatan suatu alat ukur dalam melakukan fungsi ukurnya (Aswar 1992). Semakin valid suatu alat ukur maka semakin tepat dan cermat alat ukur tersebut dalam mengukur konsep yang diteliti. Pengujian validitas konstruks (construct validity) yang digunakan oleh peneliti adalah Confirmatory Factor Analysis (CFA) dengan menggunakan SPSS for Windows versi 15. Estimasi reliabilitas dilakukan dengan menggunakan formula Alpha dari Cronbach. Alat uji yang biasa dan populer digunakan adalah uji konsistensi internal (internal consistency) dengan menggunakan koefisien Cronbach Alpha, dimana tingkat koefisien yang digunakan adalah 0,7 atau 0,6 (Hair et al., 2006).

\section{Uji Hipotesis}

Uji hipotesis dalam penelitian inidengan menggunakan regression analysis. Analisis data dilakukan melalui beberapa tahapan dengan memasukkan data kuantitatif yang didapatkan dari kuisioner yang terkumpul dan menganalisisnya dengan software SPSS 15. Goodness of fit suatu model regresi meliputi uji signifikasi parameter individual, uji signifikasi simultan dan koefesien determinan.

\section{HASIL DAN PEMBAHASAN}

\section{Pengumpulan Data}

Penelitian ini dilakukan di wilayah Daerah Istimewa Yogyakarta. Peneliti mendapatkan data penelitian melalui penyebaran kuisioner, wawancara (interview) selama kurang lebih dua bulan dari September sampai dengan Oktober 2013, dengan melibatkan bantuan duaenumerator. Sebelum menganalisis data, peneliti mengumpulkan data-data yang diperlukan. Data diperoleh dari jawaban atas pernyataan-pernyataan dalam kuesioner yang dibagikan kepada 150 responden yaitu manajer pengembang perumahan. Namun oleh karena kendala di lapangan serta waktu, hanya mampu didapatkan responden sebanyak 80 orang.

\section{Uji Validitas dan Reliabilitas}

Uji validitas instrumen dalam penelitian ini dilakukan dengan faktor analisis untuk memastikan bahwa masing-masing item pertanyaan telah mewakili konstruks yang hendak diukur. Pengujian validitas konstruks (construct validity) yang digunakan oleh peneliti adalah Confirmatory Factor Analysis (CFA) dengan menggunakan SPSS for Windows versi 15.Estimasi reliabilitas dilakukan dengan menggunakan formula Alpha dari Cronbach. Estimasi reliabilitas dilakukan untuk menguji konsistensi instrumen penelitian. Dari hasil perhitungan uji validitas dan 
reliabilitas secara keseluruhan, butir-butir pertanyaan pada variabel independen dan variabel dependen yang disusun dalam kuesioner adalah valid dan semua variabel dinyatakan reliabel.

\section{Karakteristik Responden}

Klasifikasi karakteristik responden dalam penelitian ini menggambarkan jenis kelamin, usia dan informasi pendidikan terakhir yang diperoleh dari hasil pengisian kuesioner yang telah diperoleh dari 80 responden. Dari hasil pengumpulan data diperoleh informasi tentang karakteristik responden sebagai berikut:

Tabel 1

Klasifikasi Responden

\begin{tabular}{lcc}
\hline \multicolumn{1}{c}{ Karakteristik } & Jumlah (orang) & Persentase (\%) \\
\hline Jenis Kelamin & & \\
$\quad$ Laki-laki & 68 & 85 \\
$\quad$ Perempuan & 12 & 15 \\
Usia & & \\
20-30 tahun & 14 & 17,5 \\
31-40 tahun & 22 & 27,5 \\
41-50 tahun & 32 & 40,0 \\
51-60 tahun & 12 & 15,0 \\
Pendidikan & & \\
SLTA & 14 & 17,5 \\
D2 & 2 & 2,5 \\
D3 & 14 & 17,5 \\
S1 & 42 & 52,5 \\
S2 & 8 & 10,0 \\
\hline
\end{tabular}

Sumber: Data diolah

Berdasarkan data yang diperoleh, dapat diketahui bahwa jumlah responden laki-laki merupakan yang paling banyak (85 persen). Usia responden didominasi klasifikasi usia 41-50 tahun (40 persen), sedangkan adapun pendidikan responden terbanyak meliputi pendidikan S1 (52,5 persen).

\section{Uji Hipotesis}

Uji hipotesis dalam penelitian inidengan menggunakan regression analysis. Analisis data dilakukan melalui beberapa tahapan dengan memasukkan data kuantitatif yang didapatkan dari kuisioner yang terkumpul dan menganalisisnya dengan software SPSS 15.

Jadi, koefisien regresi dari masing-masing variabel independen bernilai positif sehingga menyebabkan kenaikan pada variabel dependen. Hal ini berarti variabel kapabilitas pemasaran, kapabilitas operasiberpengaruh positif terhadap kinerja perusahaan, demikian jugamempunyai pengaruh positif terhadap integrasi 
supply chain. Pada sisi lain integrasi supply chainjuga memiliki pengaruh positif pada kinerja perusahaan.Hasil pengujian hipotesis dengan model 1, 2 dan 3 dapat dilihat pada Tabel 2.

Hasil uji regresi untuk pengaruh kapabilitas pemasaran dan kapabilitas operasi terhadap integrasi supply chain menunjukkan besarnya koefisien determinasi $\left(\mathrm{R}^{2}\right)=0,104$ yang berarti bahwa variansi integrasi supply chain yang dapat dijelaskan secara bersama-sama oleh kapabilitas pemasaran dan kapabilitas operasi adalah 10,4 persen, sedangkan sisanya 89,6 persen dapat diperjelas oleh variabel lain. Uji signifikasi simultan (uji F) menunjukkan nilai $\mathrm{F}$ test yang diperoleh adalah sebesar 3,260 dengan signifikasi 0,000, karena probabilitas 0,000 lebih kecil dari 0,104 maka dikatakan bahwa kapabilitas pemasaran dan kapabilitas operasi secara bersama-sama berpengaruh terhadap integrasi supply chain.

Tabel 2

Hasil Regression Analysis

\begin{tabular}{|c|c|c|c|c|c|c|c|c|c|c|}
\hline \multirow[b]{3}{*}{$\begin{array}{c}\text { Variabel } \\
\text { Independen }\end{array}$} & \multicolumn{10}{|c|}{ Variabel Dependen } \\
\hline & \multicolumn{5}{|c|}{ Integrasi Supply chain } & \multicolumn{5}{|c|}{ Kinerja Perusahaan } \\
\hline & $\beta$ & $\mathbf{t}$ & sig. & $\mathbf{R}^{2}$ & $\mathbf{F}$ & $\beta$ & $\mathbf{t}$ & sig. & $\mathbf{R}^{2}$ & $\mathbf{F}$ \\
\hline Kapabilitas & 0,213 & 1,039 & 0,306 & 0,104 & 3,260 & 0,729 & 0,582 & 0,564 & 0,266 & 2,463 \\
\hline Pemasaran & & & & & & & & & & \\
\hline Kapabilitas & & & & & & & & & & \\
\hline Operasi & 0,713 & 2,041 & 0,048 & & & 0,540 & 1,856 & 0,072 & & \\
\hline $\begin{array}{l}\text { Integrasi Supply } \\
\text { chain }\end{array}$ & & & & & & 0,294 & 1,385 & 0,174 & & \\
\hline
\end{tabular}

Sumber: Data diolah

Sedangkan hasil uji regresi untuk pengaruh kapabilitas pemasaran dan kapabilitas operasi terhadap integrasi supply chain menunjukkan besarnya koefisien determinasi $\left(\mathrm{R}^{2}\right)=0,266$ yang berarti bahwa variansi kinerja perusahaan yang dapat dijelaskan secara bersama-sama oleh kapabilitas pemasaran, kapabilitas operasi dan integrasi supply chain adalah 26,6 persen, sedangkan sisanya 73,4 persen dapat diperjelas oleh variabel lain. Uji signifikasi simultan (uji F) menunjukkan nilai $\mathrm{F}$ test yang diperoleh adalah sebesar 2,463 dengan signifikasi 0,000, karena probabilitas 0,000 lebih kecil dari 0,266 maka dikatakan bahwa kapabilitas pemasaran, kapabilitas operasi dan integrasi supply chain secara bersama-sama berpengaruh terhadap kinerja perusahaan.

Pada pengujian hipotesis satu dinyatakan bahwa kapabilitas pemasaran mempunyai pengaruh positif terhadap kinerja perusahaan. Pada tabel terlihat bahwa uji regresi tersebut menghasilkan nilai $\beta=0,540$, sig. $=0,072$ dan $\mathrm{t}=1,856$. Nilai ini menunjukkan bahwa pengaruh kapabilitas pemasaran terhadap kinerja perusahaan adalah positif dan signifikan, sehingga mendukung hipotesis $1 \mathrm{a}$.

Hipotesis $1 \mathrm{~b}$ menyatakan bahwa kapabilitas operasi mempunyai pengaruh positif terhadap kinerja perusahaan. Pada tabel terlihat bahwa uji regresi tersebut 
menghasilkan nilai $\beta=0,729$, sig. $=0,564$ dan $t=0,582$. Nilai ini menunjukkan bahwa pengaruh kapabilitas operasi terhadap kinerja perusahaan adalah positif dan signifikan, sehingga mendukung hipotesis $1 \mathrm{~b}$.

Hipotesis 2a menyatakan bahwa kapabilitas pemasaran mempunyai pengaruh positif terhadap integrasi supply chain. Pada tabel terlihat bahwa uji regresi tersebut menghasilkan nilai $\beta=0,213$, sig. $=0,306$ dan $t=1,039$. Nilai ini menunjukkan bahwa pengaruh kapabilitas pemasaran terhadap integrasi supply chain adalah positif dan signifikan, sehingga mendukung hipotesis $2 \mathrm{a}$.

Hipotesis $2 \mathrm{~b}$ menyatakan bahwa kapabilitas operasi mempunyai pengaruh positif terhadap integrasi supply chain. Pada tabel terlihat bahwa uji regresi tersebut menghasilkan nilai $\beta=0,713$, sig. $=0,048$ dan $t=2,041$. Nilai ini menunjukkan bahwa pengaruh kapabilitas operasi terhadap integrasi supply chain adalah positif dan signifikan, sehingga mendukung hipotesis $2 \mathrm{~b}$.

Hipotesis 3 menyatakan bahwa integrasi supply chain mempunyai pengaruh positif terhadap kinerja perusahaan. Pada tabel terlihat bahwa uji regresi tersebut menghasilkan nilai $\beta=0,294$, sig. $=0,174$ dan $t=1,385$. Nilai ini menunjukkan bahwa pengaruh integrasi supply chain terhadap kinerja perusahaan adalah positif dan signifikan, sehingga mendukung hipotesis 3 .

Hasil keseluruhan hipotesis berdasarkan analisis regresi dapat dilihat berdasarkan Tabel 3.

Tabel 3

Hasil Keseluruhan Hipotesis

\begin{tabular}{clc}
\hline No. & \multicolumn{1}{c}{ Hipotesis } & Keterangan \\
\hline H1a. & $\begin{array}{l}\text { Variabel kapabilitas pemasaran secara signifikan } \\
\text { berpengaruh terhadap kinerja perusahaan. }\end{array}$ & Terdukung \\
H1b. & $\begin{array}{l}\text { Variabel kapabilitas operasi secara signifikan } \\
\text { berpengaruh terhadap kinerja perusahaan. }\end{array}$ & Terdukung \\
H2a. & $\begin{array}{l}\text { Variabel kapabilitas pemasaran secara signifikan } \\
\text { berpengaruh terhadap integrasi supply chain. }\end{array}$ & Terdukung \\
H2b & $\begin{array}{l}\text { Variabel kapabilitas operasi secara signifikan } \\
\text { berpengaruh terhadap integrasi supply chain. } \\
\text { Variabel integrasi supply chain secara signifikan } \\
\text { berpengaruh terhadap kinerja perusahaan }\end{array}$ & Terdukung \\
\hline
\end{tabular}

\section{PEMBAHASAN}

Penelitian-penelitian tentang organisasi memberikan sejumlah saran untuk memaksimalkan kinerja perusahaan dalam situasi tersebut. Integrasi supply chain merupakan tugas perubahan untuk banyak perusahaan. Adanya dorongan yang kuat strategi Supply chain Management (SCM) hanya sedikit diketahui pengaruhnya pada kinerja perusahaan. Kebutuhan untuk suatu model yang dapat menjelaskan 
bagaimana dan mengapa integrasi menjadi suatu hal yang penting. Penelitian ini mengisi gap dalam literatur. Lebih lanjut, sangat perlu menitikberatkan kolaborasi berbagai fungsi seperti operasi dan marketing pada integrasi SCM. Kapabilitas yang dinamis menempatkan perusahaan mencapai pengaruh yang positif dalam pemberdayaan sumber daya sesuai konfigurasi, komplementari, integrasi, tetapi hanya sedikit penelitian yang mengarah ke sana.

Isu utama pada masalah seputar manajemen pemasaran dan operasi, berdasar berbagai pendekatan untuk meningkatkan kinerja supply chain secara keseluruhan. Hasil penelitian lapangan mengarah pada berbagai jalan dimana perusahaan pengembang perumahan dapat mensinkronkan pemasaran dan operasi atau rekan dalam supply chain menagement untuk meningkatkan daya saing dan profit. Informasi isu ini menjadi hal yang penting bagi manajer dan perusahaan pengembang perumahan, sehubungan dengan berbagai masalah dalam wilayah pemasaran dan operasi.

Penelitian terdahulu yang dilakukan masing-masing oleh Krasnikov dan Jayachandran (2008), terbatas pada hubungan kapabilitas pemasaran dan kapabilitas operasi dengan kinerja perusahaan saja, demikian juga penelitian Agan (2011) dilakukan hanya pada hubungan kapabilitas pemasaran dan kapabilitas operasi dengan supply chaindan Alexandru (2012) terbatas meneliti hubungan integrasi supply chain dengan kinerja perusahaan. Penelitian ini dilakukan dengan memadukan hubungan kapabilitas pemasaran dan kapabilitas operasi, integrasi supply chain dan kinerja perusahaan.

Hasil penelitian menunjukkan bahwa kelima hipotesis dalam penelitian ini didukung, dimana kapabilitas pemasaran dan kapabilitas operasi berpengaruh positif, baik terhadap integrasi supply chain maupun kinerja perusahaan. Adapun hasil lainnya menunjukkan bahwa integrasi supply chain berpengaruh positif pada kinerja perusahaan.

a. Kapabilitas Pemasaran dan Kapabilitas Operasi serta Kinerja Perusahaan.

Penelitian ini menunjukkan bahwa kapabilitas dua fungsi tersebut berkontribusi positif terhadap kinerja perusahaan. Kontribusi ini terutama pada kegiatankegiatan berhubungan dengan apa yang diproduksi, bagaimana memproduksi dan mengantarkan produk ke tangan konsumen. Dalam hal ini kapabilitas merupakan merupakan sumber daya penting untuk keunggulan bersaing dan kinerja yang superior, sehingga kontribusi kapabilitas dalam dua fungsi tersebut mendukung hasil kinerja perusahaan.

b. Kapabilitas Pemasaran dan Kapabilitas Operasi serta Integrasi Supply chain.

Keterpaduan kapabilitas kedua fungsi ini sangat mendukung dalam integrasi supply chain. Hal ini ditunjukkan dalam kontribusi positif kedua kapabilitas tersebut pada integrasi supply chain. Hubungan interaction ditunjukkan dalam 
pengukuran kinerja seperti time, quality dan flexibility. Demikian juga joint decisions dapat dilakukan dalamkonteks penentuan harga, positioning, keputusan product line, yang berhubungan dengan operasi seperti teknologi dan desain produksi. Praktik interaksi kedua fungsi tersebut dalam transfunctional sangat komplek dan mendukung dalam kegiatan supply chain perusahaan.

c. Integrasi Supply chain dan Kinerja Perusahaan.

Hasil penelitian menunjukkan peran positif proses integrasi supply chain pada kinerja perusahaan. Dalam konteks ini peran supply chain management yang baik menjadi sangat penting artinya. Keunggulan kompetitif $S C M$ dilakukan melalui bagaimana perusahaan mampu mengelola aliran barang atau produk dalam suatu rantai supply. Dengan kata lain model SCM mengaplikasikan bagaimana suatu jaringan kegiatan produksi dan distribusi suatu perusahaan dapat bekerja bersamasama untuk memenuhi tuntutan konsumen. Hal yang penting adalah penyerahan/pengiriman produk secara tepat waktu demi memuaskan konsumen, mengurangi biaya, meningkatkan segala hasil dari seluruh supply chain (bukan hanya satu perusahaan), mengurangi waktu, memusatkan kegiatan perencanaan dan distribusi. Namun demikian jalinan kerja sama dengan mitra supply chain juga penting. Kemitraan yang kuat menekankan pada kerja sama yang panjang, mencakup perencanaan yang lebih baik dan upaya pemecahan masalah bersama. Supply chain integration meningkatkan efisiensi dan produktifitas. Integrasi pada supply chain merupakan kunci untuk mencapai keunggulan kompetitif perusahaan.

\section{SIMPULAN DAN KETERBATASAN}

\section{Simpulan}

Penelitian ini mendukung penelitian-penelitian terdahulu, dimana kapabilitas pemasaran dan kapabilitas operasi berperan positif dalam suatu perusahaan dalam hal ini kinerja perusahaan. Demikian juga mendukung penelitian tentang peran supply chain management dalam hal ini integrasi kontribusi supply chain pada kinerja perusahaan.

Secara umum yang dapat disimpulkan dalam penelitian ini yaitu keterpaduan (integrasi) fungsi pemasaran dan operasi sangat penting guna mendukung proses integrasi supply chain yang dilakukan perusahaan. Selanjutnya proses integrasi supply chain yang melibatkan keterpaduan kapabilitas pemasaran dan kapabilitas operasi serta kemitraan dengan pemasok merupakan kunci yang sangat penting untuk kinerja perusahaan.

\section{Keterbatasan}

Keterbatasan penelitian ini yaitu interaksi antara kapabilitas operasi dan pemasaran belum diteliti, hal ini karena keterbatasan jumlah responden, dimana 
penelitian ini terbatas pada jumlah responden 80 orang, sehingga menggunakan analisis regresi. Dalam penelitian selanjutnya bisa dikembangkan penelitian integrasi marketing dan operasi dengan interaksi kapabilitas pemasaran dan kapabilitas operasi menggunakan alat analisis Structural Equity Model(SEM).

\section{DAFTAR PUSTAKA}

Agan, Y. 2011. Impact of operations, marketing, and information technology capabilities on supply chain integration. Journal of Economic and Social Research. Vol.13 No.1: 27-56.

Alexandru, C. 2012. The impact of supply chain management performance on organization performance. Journal of Electrical \& Electrones Engineering. Vol.5 No.2 (October).

Anatan, L. 2006. Pengaruh lingkungan bisnis, strategi operasi, dan teknologi sebagai variabel pemoderasi terhadap kinerja operasional perusahaan: Studi perusahaan manufaktur di Indonesia. Jurnal Widya Manajemen Akuntansi.

Arumugam, V. C., dan R. Mojtahedzadeh. 2011. Relationship between supply chainmanagement practices and performance in the iranian industries: A theoretical approach. International Journal of Academic Research. Vol.3 No.4 (July): 594-635.

Bowersox, D. J., D. J. Closs, dan T. P. Stank. 1999. Century logistic making supply chain integration a reality. Oak Brook, II. Council of Logistic Management.

Calantone, R., R. Garcia, dan C. Droge. 2003. The effects of environmental turbulence on new product development strategy planning. Journal of Product Innovation Management. Vol.20: 90-103.

Chase, R. B., F. R. Jacobs, dan N. J. Aquilano. 2004. Operations management for competitive advantage. $10^{\text {th }}$ ed. Singapore: McGraw-Hill/Irwin.

Chopra. 2010. Supply Chain Management: Strategy, Planning, and Operation. 4EdPearson Education.

Day, G. S. 1994. The capabilities of market driven organizations. Journal of marketing. Vol.58 (Oktober): 37-52.

Deane, R. H., P. P. Mc Dougall, dan V. B. Gargeya. 1991. Manufacturing and marketinginterdependece in new venture firm:an empirical study. Journal of Operation Management. Vol.10 No.3: 329-343.

Drucker P. 2007. The Practice of Management. Oxfords Butterworth-Heineimainn.

Ellitan, L., dan L. Anatan. 2008. Manajemen Strategi Operasi. Bandung: Penerbit Afabeta. 
Fitzsimmons, J., P. Kouvelis, dan D. Mallick. 1991. Design strtategy and its interface with manufacturing andmarketing. Journal of Operational management. Vol.10: 398-418.

Flyn, B. B., R. G. Scroeder, dan Sakakibara. 1995. The impact of quality mangement practices on performance and competitive advantage. Decision Science. Vol.26. No.5: 69-92.

Gunasekaran A., C. Patel, dan Mc. Ganhey. 2004. A framework for supply chain performance measurement. International Journal of Producting Economic. Vol.87: 333-347.

Hale, T., dan C. R. Moberg. 2005. Improving supply chain disaster preparedness: A decision process for secure site location. International Journal of Physical Distribution \& Logistics Management. Vol.35 No.3: 195-207.

Heizer, J., dan R. Barry. 2001. Operations management. $6^{\text {th }}$ ed. Upper Saddle River, N.J: Prentice Hall, Inc.

Ho, T. H., dan C. S. Tang. 2004. Introduction to special issue on marketing and operations management interfaces and coordination. Management Science. Vol.50 No.4: 429-430.

Ho, T. H., dan Y. S. Zheng. 2004. Setting customer expectation in service delivery: An integrated marketing-operations perspective. Management Science. Vol.50 No.4: 479-488.

Kohli, A., dan B. Jaworski. 1990. Market orientation: The construct research proportion and mangerial imlications. Journal of Marketing. 54 (April): 1-18.

Krasnikov, A., dan S. Jayachandran. 2008. The relative impact of marketing, research and development, and operations capabilities on firm performance. Journal of marketing. Vol.72(July): 1-11.

Krause, D. R., T. V. Scannell, dan R. J Calantone. 2000. A structural anaysis of the effectiveness of buying firms, strategies to improve supplier performance. Decision Science. Vol.31: 33-35.

Kwon, I. W., dan T. Suh. 2005. Trust, commitment and relationships in supply chain management: A path analysis. Supply chain Management: An International Journal. Vol.10 No.1: 26-33.

Ma'arif, M. S., dan H. Tanjung. 2003.Manajemen Operasi. Jakarta: Penerbit PT Gramedia Widisarana.

Maloni, M., dan W.C. Benton. 2000. Power influences in supply chain. Journal of Business Logistic. Vol.21 No.1: 49-63. 
Min, S., dan J. T. Mentzer. 2000. The role of marketing in supply chain management. International Journal of Phsycal Distribution \& Logistic Management. Vol.30: 765-787.

Momeni, M., A. Monavarian, E. Shaabani, dan R. Ghasemi. 2011. A conceptual model for knowledge management process capabilities and core competencies by SEM the case of Iranian automotive Industry. European Journal of Social Sciencies. Vol.22 No.4.

Narasimhan, R. 2001. Manufacturing agility and supply chain mangement practices. Production and Inventory. Management Journal. Vol.40 No.1: 4-10.

Piercy, N. 2010. Improving marketing, operations cross fungctional relationship. Journal of Strategic Marketing. Vol.18 No.4 (July): 337-356.

Porter, M. 1995. Competitive Advantage-Creating and Sustaining Superior Performance. New York: free press a division of Mc Millan, Inc.

Purnomo, H.2008. Inovasi produk: Keterkaitan manajemen pemasaran dan operasi. Jurnal Bisnis dan Akuntansi Equillibrium. Vol.1 No.2: 53-67.

Sadeh, E., L. Mousavi, dan S. Sadeh. 2011. Presenting a framework to study linkage among TQM practices, supply chain management practices, and performance using Dematel Technique. Australian Journal of Basic and Apllied Sciences. Vol.5 No.9: 885-890.

Sahwey, R., dan C. Piper. 2002. Value creation through enriched marketingoperation interface. Journal of Operation Management. Vol.20: 259-271.

Setiawan, A. I., dan H. Santosa. 2006. Integrasi supply chain pada industri tekstil: Survei pada retailer dan grosir di Jawa Tengah dan Jawa Timur. Jurnal Empirika. Vol.19 No.1: 81-97.

Song, M. C. D., S. Hanvanich dan R. Calantone. 2005. Marketingand technology resource complementary: An analysis of their interaction effect in two inveronmental contexts. Strategic Management Journal. Vol.26: 259-276.

Souder, W. E., dan R. K. Moenaert. 1992. Integrating marketing and R\&D project personnel within innovation projects: An information uncertainty model. Jurnal of Managemnt Study. Vol.29: 485-502.

Tatikonda, M. V.,dan M. M. M. Weiss. 2001. Integrating operations and marketing perspectives of product innovation:The influence of organizational process factors and capabilities on development performance.Management Science. Vol.47 No.1 (January): 151-172.

Watanabe, R. 2001. Supply chainmanagement: Konsep dan teknologi. Usahawan XXX, No.2(Februari): 8-11. 
Widayanto, G. 1995. Manajemen rantai suplai: Suatu jawaban menghadapi kompetisi berbasis waktu. Usahawan XXIV. No.12 (Desember): 14-18.

Wisher, J.D. 2003. A Structural equation model of supply chain management strategies and firm performance. Journal of Business Logistics. Vol.24 No.1.

Vikery, K. S., C. Droge, dan R. E. Markland. 1994. Production comptence and business strategy: Do they affect business performance.Decision Science. Vol.24 No.2: 435-455.

Zabidi, Y. 2001. Supply chain management: Teknik terbaru dalam mengelola aliran material/produk dan informasi dalam memenangkan persaingan. Usahawan XXX. No.2 (Februari): 3-7. 
